\title{
Seroprevalence of peste des petits ruminants among domestic small and large ruminants in the semi-arid region of North-eastern Nigeria
}

\author{
Abdul-Dahiru El-Yuguda, Saka Saheed Baba, Abdul Ganiyu Ambali and Godon O Egwu ${ }^{1}$ \\ Animal virus Research Laboratory Department of Veterinary Microbiology and Parasitology PMB 1069 Maiduguri nigeria; \\ 1. Department of Veterinary medicine University of Ilorin, Nigeria \\ Corresponding author: El-Yuguda Abdul-Dahiru, email:abduldahiru@gmail.com \\ Received: 22-06-2013, Revised: 01-08-2013, Accepted: 03-08-2013, Published online: 07-09-2013
}

doi: 10.14202/vetworld.2013.807-811 How to cite this article: El-Yuguda Abdul-Dahiru, Baba SS, Ambali AG and Egwu GO (2013) Seroprevalence of peste des petits ruminants among domestic small and large ruminants in semi-arid region of north-eastern Nigeria, Veterinary World 6(10): 807-811.

\begin{abstract}
Background: Recent changes in the host range of peste des petits ruminants (PPR) virus coupled with the presence of a huge ruminant population in the study area has stimulated our interest to carry out a sero-survey for PPR among the different domestic ruminant populations of semi-arid region of North-eastern (NE) Nigeria.
\end{abstract}

Materials and Methods: The prevalence of PPR virus antibodies among domestic animals (goat, sheep, cattle and camel) populations in NE Nigeria was studied using virus neutralisation test (VNT) and competitive enzyme-linked immunosorbent assay (c-ELISA).

Results: An overall seroprevalence of 57\% and 55\% were revealed using VNT and c-ELISA, respectively. Significant difference $(p<0.05)$ in the prevalence of PPR antibodies was noted between the different species of animals tested. Highest seroprevalence of $76.5 \%$ was found in sheep followed by a decreasing order of prevalence in goat $51.6 \%$, camels $27.8 \%$ and cattle $16.7 \%$. Similar pattern of prevalence was noted when the sera were tested for PPR using c-ELISA antibody. There was no significant difference in the sensitivity of both the procedures (VNT and c-ELISA) when used for the detection of PPR antibody in test sera. However, differences were noted in their specificity based on the degree of cross reactivity between PPR and rinderpest (RP) antibodies. Higher percentage of PPR positive sera (goats 64.8\% and sheep 63.8\%) cross-reacted with RP virus in VNT. None of the PPR positive sera from cattle and camels cross-reacted with RP virus in VNT and c-ELISA. Significant difference in gender and age was noted in the prevalence of PPR antibody among goats and sheep. Specificall, higher prevalence was found in females and the seroprevalence increased with age among the different age groups of goats studied. Analysis of the seasonal distribution of prevalence of PPR antibody in positive samples did not reveal any significant difference between seasons.

Conclusion: We conclude that PPR virus is actively circulating among the ruminant and dromedary populations and that the infection may be endemic in the study area. Significant findings from our study indicate that cattle and camel could play a key role in the epidemiology of PPR, especially in areas like the one under this study where small ruminants are reared alongside cattle and/or camels. Further studies are necessary to fully elucidate, the pivotal roles of cattle and camel in the transmission cycle of PPR virus.

Keywords: competitive enzyme linked immunosorbent assay, ruminant, semi-arid region, seroprevalence, virus neutralisation test

\section{Introduction}

Ruminants are a major component of the livestock sub-sector in most parts of the world including Nigeria [1]. Nigeria is blessed with abundant livestock resources with most of the animals being concentrated in the northern parts of the country [2]. The semi-arid zone of north-eastern (NE) Nigeria is reported to account for about $25 \%$ of each of the ruminant population of Nigeria which is estimated at 13.3 million cattle [3]; 20.1 million sheep and 34.5 million goats $[4,5]$. Efforts to improve the productivity of livestock in Nigeria have been hindered by a variety of factors including infectious diseases that results in countless number of animal deaths [6]. In an economic point of view, one of the important of these diseases is

Copyright: The authors. This article is an open access article licensed under the terms of the Creative Commons Attribution License (http://creativecommons.org/licenses/by/2.0) which permits unrestricted use, distribution and reproduction in any medium, provided the work is properly cited. the peste des petits ruminants (PPR) [7]. This disease is among the greatest threats to the successful livestock production and food security in the affected areas [8, 9]. PPR is an economically important, rapidly spreading, acute or subacute viral disease of domestic and few wild small ruminants $[10,11]$. The disease is characterized by high morbidity and heavy mortality, with symptoms ranging from depression, pyrexia, oculo-nasal discharges, pneumonia, stomatitis, to diarrhea $[9,10,12,13]$. This disease was found to occur in most of the African countries that are situated in a wide belt between the Sahara and the Equator, Middle East, Arabian Peninsula and south India [14-16]. The disease is now spreading from Afghanistan into the neighbouring countries of the former Soviet Union and has recently entered China. This disease is proving to be costly with an increasingly significant impact on economy of these countries $[14,16]$. It is considered as one of the most important health constraints in the 


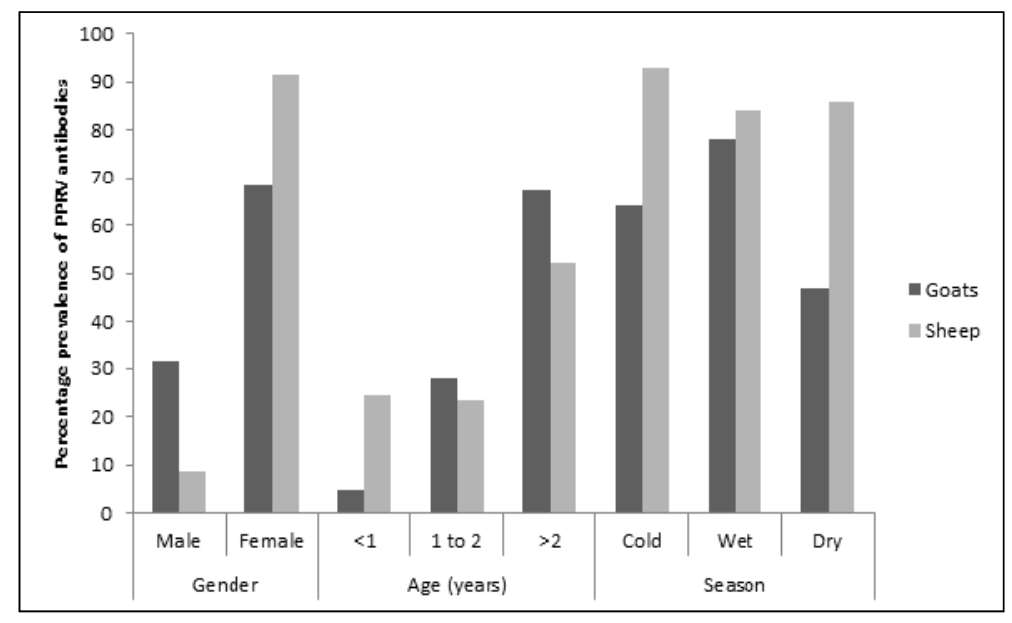

Figure-1. Gender, age and seasonal distribution of PPR VN antibodies among small ruminants in the semi-arid NE zone of Nigeria

rearing of small ruminants $[14,17]$ with a significant impact on the financial status of rural farmers $[18,19]$.

For a better understanding of the epidemiology of PPR among the ruminant populations of the semi-arid NE region of Nigeria, both large and small ruminants were sampled and analysed serologically for evidence of PPR.

\section{Materials and Methods}

Test sera: Blood samples were collected randomly by venipuncture method from sheep, goats, cattle and camel that had no previous history of vaccination against PPR or rinderpest (RP) at slaughter houses, watering points and individual flocks in the semi-arid $\mathrm{NE}$ region of Nigeria. A total of 2,879 samples consisting of 1,571 goats, 1,008 sheep, 192 cattle and 108 camels were collected. Blood samples were allowed to clot and then stored at $4{ }^{\circ} \mathrm{C}$ overnight. Sera were harvested from the clotted blood after centrifugation at 1,500 rpm for 10 minutes, and stored in sterile $2 \mathrm{ml}$ cryotubes. The sera were stored at $-20^{\circ} \mathrm{C}$. The samples were collected from slaughter houses, organised farms, rural dwellings, and at watering sites. The serum samples were subjected to virus neutralization test (VNT) and competitive enzymelinked immunosorbent assay (c-ELISA).

Virus neutralization test: Vero cells (R133), PPR vaccine virus (Capripestovax ${ }^{\circledR}$ LANAVET Garoua, Cameroon), RP vaccine virus, PPR and RP positive sera were obtained from LANAVET Garoua, Cameroon. Both vaccine viruses were used at $10^{3} \mathrm{TCID}_{50}$. The test sera used in this study were heat inactivated at $56^{\circ} \mathrm{C}$ for 30 minutes prior to using them. The neutralizing antibody titres of serum samples were determined according to the protocol described in OIE manual [20]. The reciprocal of the highest dilution of sera showing complete inhibition of cytopathic effect was recorded as $\mathrm{VN}$ titre.

Competitive enzyme-linked immunosorbent assay: The PPR and RP competitive ELISA kits manufactured by the Institute for Animal Health Pirbright Surrey,
England and supplied by BDSL, were provided by LANAVET Garoua Cameroon. The c-ELISA used for the detection of antibodies to PPR and RP in the serum samples is based on two specific monoclonal antibodies against the hemagglutinin (HA) protein of PPR virus and the other one specific against HA protein of RP virus. The tests detect only antibodies to specific virus and gives no cross reactivity between the two viruses. The samples with PI (full form of PI) $>50 \%$ were considered as positive

Statistical analysis: The data were analyzed statistically using student t-test and at a 5\% level of statistical significance.

\section{Results}

A total of 2,879 serum samples, comprising of 1,571 goat sera, 1,008 sheep sera, 192 cattle sera and 108 camel sera were tested for PPR antibodies using VNT and c-ELISA. The results of the VNT revealed PPR antibody prevalence rates of $51.6 \%, 76.5 \%$, $16.7 \%$ and $27.8 \%$ for goats, sheep, cattle and camels, respectively. While the c-ELISA showed a seroprevalence of $50.4 \%, 73.2 \%, 16.7 \%$ and $25.9 \%$ for goats, sheep, cattle and camels, respectively (Table 1). Significant difference $(\mathrm{P}<0.05)$ was noted in the percentage of seroprevalence between males and females in both goats and sheep (Figure 1). The age distribution showed significant difference in percentage of seroprevalence among the different age groups of goats with seroprevalence being increased with an increase in age (Figure-1). Sheep that are aged above two years showed statistical difference in prevalence when compared to the other age groups of sheep tested (Figure-1). The seasonal distribution of the positive samples among the small ruminant species did not show any statistical difference $(\mathrm{P}>0.05)$ (Figure $-1)$. When the PPR positive samples were tested for RP antibodies using VNT and c-ELISA, it was observed that $64.8 \%$ and $63.8 \%$ of the PPR positive goat and sheep samples were found to cross neutralise with RP using VNT, but none of these positive samples was found to be positive for RP antibodies using c-ELISA 
Table-1. Prevalence of PPR VN antibodies in the sera of some ruminants in the semi-arid region of NE Nigeria

\begin{tabular}{|c|c|c|c|c|c|c|c|c|c|c|c|}
\hline \multirow[t]{2}{*}{ Animal Species } & \multirow{2}{*}{$\begin{array}{l}\text { No. }(\%) \\
\text { positive }\end{array}$} & \multicolumn{9}{|c|}{ Reciprocal of PPR VN antibody titres (\%) } & \multirow[b]{2}{*}{5120} \\
\hline & & 10 & 20 & 40 & 80 & 160 & 320 & 640 & 1280 & 2560 & \\
\hline & $810(51.6)$ & 135( & $126(21.7)$ & $30(5.2)$ & $69(1$ & $114(1.9)$ & $138(2.2)$ & $99(17.0)$ & $90(15.5)$ & $9(1.6)$ & - \\
\hline 1008) & 771 (76.5) & $84(11.0)$ & $51(6.7)$ & $66(8.6)$ & 93 (12.2) & $147(19.2)$ & $153(20.0)$ & $108(14.1)$ & $57(6.7)$ & $9(1.2)$ & $3(0.4)$ \\
\hline Cattle $(n=192)$ & $32(16.7)$ & - & $6(18.8)$ & $8(25)$ & $6(18.8)$ & $8(25)$ & $4(12.5)$ & - & - & - & - \\
\hline Camels $(n=108)$ & $30(27.8)$ & $3(10.0)$ & $6(20.0)$ & $6(20.0)$ & $6(20.0)$ & $6(20.0)$ & $3(10.0)$ & - & - & - & - \\
\hline
\end{tabular}

* - Negative

Table-2. Results of VN test and c-ELISA in differentiating PPR from RP antibodies in the sera of some ruminants in the semiarid region of NE Nigeria

\begin{tabular}{|c|c|c|c|c|c|c|c|c|c|c|c|c|c|c|c|c|}
\hline \multirow{3}{*}{$\begin{array}{l}\text { Reciprocal } \\
\text { of PPR VN } \\
\text { antibody Titre }\end{array}$} & \multicolumn{4}{|c|}{ Goats } & \multicolumn{4}{|c|}{ Sheep } & \multicolumn{4}{|c|}{ Cattle } & \multicolumn{4}{|c|}{ Camels } \\
\hline & \multicolumn{2}{|c|}{ VN } & \multicolumn{2}{|c|}{ C-E LISA* } & \multicolumn{2}{|c|}{ VN } & \multicolumn{2}{|c|}{ C-ELISA } & \multicolumn{2}{|c|}{ VN } & \multicolumn{2}{|c|}{ C-ELISA } & \multicolumn{2}{|c|}{ VN } & \multicolumn{2}{|c|}{ C-ELISA } \\
\hline & PPR & RP & PPR & $\overline{\mathbf{R P}}$ & PPR & $\overline{R P}$ & PPR & $\overline{\mathbf{R P}}$ & PPR & RP & PPR & RP & PPR & $\overline{\mathbf{R P}}$ & PPR & $\mathbf{R P}$ \\
\hline 10 & 135 & - & 123 & - & 84 & 6 & 63 & - & - & - & - & - & 3 & - & 1 & - \\
\hline 20 & 126 & 30 & 120 & - & 51 & 15 & 45 & - & 6 & - & 6 & - & 6 & - & 6 & - \\
\hline 40 & 30 & 15 & 30 & - & 66 & 42 & 66 & - & 8 & - & 8 & - & 6 & - & 6 & - \\
\hline 80 & 69 & 60 & 69 & - & 93 & 84 & 93 & - & 6 & - & 6 & - & 6 & - & 6 & - \\
\hline 160 & 114 & 105 & 114 & - & 147 & 114 & 147 & - & 8 & - & 8 & - & 6 & - & 6 & - \\
\hline 320 & 138 & 126 & 138 & - & 153 & 78 & 153 & - & 4 & - & 4 & - & 3 & - & 3 & - \\
\hline 640 & 99 & 99 & 99 & - & 108 & 90 & 108 & - & - & - & - & - & - & - & - & - \\
\hline 1280 & 90 & 81 & 90 & - & 57 & 51 & 51 & - & - & - & - & - & - & - & - & - \\
\hline 2560 & 9 & 9 & 9 & - & 9 & 9 & 9 & - & - & - & - & - & - & - & - & - \\
\hline 5120 & - & - & - & - & 3 & 3 & 3 & - & - & - & - & - & - & - & - & - \\
\hline Total & $\begin{array}{l}810 \\
(51.6)\end{array}$ & $\begin{array}{l}525 \\
(64.8)\end{array}$ & $\begin{array}{l}792 \\
(50.4)\end{array}$ & - & $\begin{array}{l}771 \\
(76.5)\end{array}$ & $\begin{array}{l}492 \\
(63.8)\end{array}$ & $\begin{array}{l}738 \\
(73.2)\end{array}$ & - & $\begin{array}{l}32 \\
(16.7)\end{array}$ & - & $\begin{array}{l}32 \\
(16.7)\end{array}$ & - & $\begin{array}{l}30 \\
(27.8)\end{array}$ & - & $\begin{array}{l}28 \\
(25.9)\end{array}$ & - \\
\hline
\end{tabular}

C-ELISA - The numbers indicates samples that were positive for PPR using c-ELISA out of the corresponding samples that were positive at that titre using VN test; $-{ }^{* *}=$ Negative; RP - Rinderpest; PPR - Peste des petits ruminants

(Table-2). No such cross-reactivity was observed among the cattle and camel samples.

\section{Discussion}

This sero-epidemiological survey for PPR antibodies among goats and sheep in the Sahel region of NE Nigeria revealed that PPR infection of the two species is widely distributed with sheep showing a higher percentage of prevalence rate than goats. The prevalence of PPR antibodies in some parts of Borno state of Nigeria were earlier reported by Taylor [21] who also observed a higher prevalence in sheep than in goats. On the other hand, Shamaki et al. [4] observed an opposite trend in these prevalence rates. Nevertheless, it is important to note that both the workers reported a high prevalence of PPR among the two species in this area. The differences between the present observation and that of these workers could be primarily because they sampled goats of different breeds that belong to other parts of the southern regions of the state unlike our study where the samples were collected from $\mathrm{NE}$ region. A difference in the sensitivity to PPR virus, which was correlated to breed rather than to the virus, was reported among various breeds of goats [22, 23]. PPR is the singular most important cause of morbidity and mortality among small ruminants, for which the most effective form of protection is through vaccination or an eventful recovery from natural infection. Because there is no history of vaccination against PPR in the present study area, the prevalence of high PPR antibodies in the population from this region is a clear indication of a high activity of the virus in this particular environment. The overall seroprevalence of $55 \%$ observed in this study agrees well with the findings of $55.2 \%$ in Uganda [24], 55.95\% in Saudi Arabia [13], 61.8\% in Sudan [25], 48.5\% in Pakistan [9] and 42.8\% in Tanzania [26], but disagrees with $1.7 \%$ in Ethiopia [27]. Our results show how vulnerable the small ruminant populations of this region could be to other secondary infections as a result of infection with PPR virus. This is because PPR virus like most morbilliviruses is known to induce immunosuppression in its natural host [28,29]. Some workers have however, reported differences in the virulence of the different lineages of the PPR virus. For example, the lineage I (e.g. Cote d'Ivoire 89, Guinea Conakry, Bissau Guinea, etc.) cause per acute to acute disease, lineage II (e.g. Nigeria 75/1) cause mild to in apparent disease, lineage III (e.g. Sudan Sennar) cause acute to mild disease and lineage IV (e.g. India Calcutta) cause acute disease [22]. Furthermore, because goats are more susceptible to PPR than sheep, it is likely that the number of goats carrying PPR virus neutralising antibodies observed in this study were the ones that survived a previous infection. While the high neutralising PPR antibodies in the sheep may be because sheep only suffer mild to inapparent infection with the virus or this may be attributed to a higher recovery rate and a greater longevity of sheep verses goats which is similar to the serological profile reported earlier by some workers [30, 31, 32]. Some workers have reported a PPR outbreak in a flock of sheep and goats with only the goats being affected [33, 34]. Similar to the reports of Luther et al. [35] and Abdalla et al. [25] we have also observed a significant statistical difference in the age and sex specific PPR prevalence rates among either species of animals. In the present study, there was no significant difference in 
the seasonal prevalence of the PPR infection among both the goats and sheep populations. El-Yuguda et al. [36] had earlier reported that the disease can persist on a year round basis with a tendency to cause increased number of infections during the raining season. Therefore, an increase in incidence reflects an increase in the number of susceptible young goats recruited into the flocks rather than a seasonal upsurge in the viral activity, since its upsurge generally peaks during kidding seasons [37]. Moreover, the susceptibility of young animals aged 3 to 18 months was documented to be very high, as they were more severely affected than adults or unweaned animals [24].

In this study we observed that serum samples that showed high titres of VN PPR antibodies $(\geq 1: 20)$ exhibited a degree of cross neutralisation between PPR and RP antibodies. The only difference was that the RP virus antibody titres never exceeded 1:40. Taylor [20] had earlier reported that PPR infected animals produce cross-neutralising antibodies against RP virus, although always below the PPR virus neutralizing antibody levels. Interestingly, however, c-ELISA tests did not show the cross reactivity that we observed with the VN test.

This is the first study to report the seroprevalence of PPR among the bovine and dromedary populations in the NE region of Nigeria. Abraham et al. [38] had earlier reported seroprevalence of PPR among cattle and camels in Ethiopia, but with a lower percentage of prevalence than reported here. Because none of the samples tested positive for RP antibodies using either VNT or c-ELISA, the results could be an indication of natural transmission of the virus under field conditions.

\section{Conclusion}

A major interpretation of our findings is that the cattle and camel population could play a role in the epidemiology of PPR, especially in areas like the one under this study where small ruminants are reared alongside cattle and/or camels. Our results may also indicate an absence of RP virus infections in the study area. Further studies are necessary to fully elucidate, the pivotal roles of cattle and camel in the transmission cycle of PPR virus.

\section{Authors' contributions}

The first author was a PhD student in the Department of Veterinary Microbiology and Parasitology University of Maiduguri Nigeria while the remaining authors were the supervisory team of the student.

\section{Acknowledgements}

The authors acknowledge with thanks the technical assistance of Ahmet Mousa of Lanavet Garoua Cameroon. The first author is a $\mathrm{PhD}$ student in the Department of Veterinary Microbiology and Parasitology University of Maiduguri Nigeria. This study was partly funded by the University of Maiduguri staff development grant.

\section{Competing interests}

The authors declare that they have no competing interest.

\section{References}

1. Odo, B. I. (2003) Comparative study of some prevalent diseases of ecotype goats reared in southeastern Nigeria. Small Rumin. Res., 50:203-207.

2. Egwu, G. O., Onyeyili, P. A., Chubuzo, G. A. and Ameh, J. A. (1995) Improved productivity of goats and utilization of goat milk in Nigeria. Small Rumin. Res., 16:195-201.

3. Ngere, L. O., Adu I. F. and Okubanjo, I. O. (1984) The indigenous goats of Nigeria. Animal genetics resource information FAO Rome, 3:1-9.

4. Shamaki, D., Olaleye, O. D., Obi, T. U., Diallo, A., Majiyagbe, K. A. and Lombin, L. H. (2004) Peste des petits ruminants (PPR) in Nigeria: serology and molecular epidemiology. Vom J. Vet. Sci., 1(1):8-27.

5. Makun, H. J., Mohammad, I. R., Olorunju, S. A. S., Otarus, S. M. and Osuhor, C. U. (2006) Growth performance of Sahelian and red Sokoto kids fed Digitaria simutsh hay supplemented with concentrate. Nig. Vet.J.,1:1-7.

6. Okoli, I. C. (2003) Incidence and modulating effects of environmental factors on trypanosomosis, peste des petit ruminants (PPR) and bronchopneumonia of West African dwarf goats in Imo state, Nigeria. Livestock Research for Rural Development, 15 (9): 1-7.

7. Sen, A., Saravanan, P., Balamurugan, V.,Sudhakar, S. B., Bhanuprakash, V., Parida, S. and Singh, R. K. (2010) Vaccines against peste des petits ruminants virus. Expert Rev Vaccines. 9(7):785-96.

8. Batten, C. A., Banyard, A. C., King, D. P., Henstock, M. R., Edwards, L., Sanders, A., Buczkowski, H., Oura, C. C. and Barrett, T. (2011) A real time RT-PCR assay for the specific detection of Peste des petits ruminants virus. J Virol Methods. 171(2):401-4.

9. Zahur, A. B., Ullah, A., Irshad, H., Hameed, A., Jahangir, M., Farooq, M. S. (2011) Sero-epidemiology of peste des petits ruminants (PPR) in Pakistan. Prev Vet Med. 102(1):8792.

10. Muse, E. A., Karimuribo, E. D., Gitao, G. C., Misinzo, G., Mellau, L. S. B., Msoffe, P. L. M., Swai, E. S. and Albano, M. O. (2012) Epidemiological investigation into the introduction and factors for spread of Peste des Petits Ruminants, southern Tanzania. Onderstepoort Journal of Veterinary Research 79(2), Art. \#457, 6 pages.

11. Saravanan, P., Sen, A., Balamurugan, V., Bhanuprakash, V., Palaniswami, K. S., Nachimuthu, K., Thangavelu, A., Dhinakarraj, G., Hegde, R. and Singh, R. K. (2010) Comparative efficacy of peste des petits ruminants (PPR) vaccines. Biologicals. 38(4):479-85.

12. Khalafalla, A. I., Saeed, I. K., Ali, Y. H., Abdurrahman, M. B., Kwiatek, O., Libeau, O., Obeida, A. A. and Abbas, Z. (2010) An outbreak of peste des petits ruminants (PPR) in camels in the Sudan. Acta Tropica 116:161-165.

13. Elshemey, T., M. and Mahmoud, M., A. (2011) Seroprevalence of antibodies against peste des petits ruminants (PPR) virus in sheep and goat in Kingdom Saudia Arabia. Alexandria J. Vet. Sci., 32 (1): 175-182.

14. Balamurugan, V., Sen, A., Venkatesan, G., Yadav, V., Bhanuprakash, V. and Singh, R. K. (2010) Isolation and identification of virulent peste des petits ruminants viruses from PPR outbreaks in India. Tropical Animal Health and Production, 42:1043-1046.

15. Lefevre, P. C. and Diallo, A. (1990) Peste des petits ruminants. Rev. Sci. Tech., 9(4):935-981.

16. Banyard, A. C., Parida, S., Batten, C., Oura, C., Kwiatek, O. and Libeau, G. (2010) Global distribution of peste des petits ruminants virus and prospects for improved diagnosis and control. J Gen Virol., 19 (Pt 12):2885-97.

17. Yener, Z., Sağlam, Y. S., Temur, A. and Keleş, H. (2004) Immunohistological detection of Peste des petits ruminants viral antigens in tissues from cases of naturally occurring 
pneumonia in goats. Small Rumin. Res., 51:273-277.

18. Dhar, P., Sreenivasa, B. P., Barrett, T., Corteyn, M., Singh, R. P. and Bandyopadhyay, S. K. (2002) Recent epidemiology of peste des petits ruminants virus (PPRV). Vet. Microbiol., 88: 153-159.

19. Diallo, A. (2006) Control of PPR and poverty alleviation? J. Vet. Med. B., 1:11-13.

20. OIE (2012) Peste des petits ruminants In: OIE manual of diagnostic tests and vaccines for terrestrial animals. Pp1-12.

21. Taylor, W. P. (1979) Serological studies with the virus of Peste des petits ruminants in Nigeria. Res. Vet. Sci., 26:236242.

22. Couacy-Hymann, E., Bodjo, C., Danho, T., Libeau, G. and Diallo, A. (2005) Evaluation of the virulence of some strains of PPR virus (PPRV) in experimentally infected west African dwarf goats. The Veterinary Journal, 173(1):178-183.

23. Diop, M., Sarr, J. and Libeau, G. (2005) Evaluation of novel diagnostic tools for peste des petits ruminants virus in naturally infected goat herds. Epidemiology and Infection, 133(4): 711-717.

24. Luka, P. D. Erume, J., Mwiine, F. N. and Ayebazibwe, C. (2011) Seroprevalence of Peste des petits ruminants Antibodies in Sheep and Goats after Vaccination in Karamoja, Uganda: Implication on Control. International Journal of Animal and Veterinary Advances 3(1): 18-22.

25. Abdalla, A. S., Majok, A. A., El Malik, K. H. and Ali, A. S. (2012) Sero-prevalence of peste des petits ruminants virus (PPRV) in small ruminants in Blue Nile, Gadaref and North Kordofan States of Sudan. Journal of Public Health and Epidemiology, 4(3): 59-64.

26. Swai, E. S., Kapaga, A., Tinuga, D., Joshua, G. and Sanka, P. (2009) Prevalence and distribution of Peste des petits ruminants virus antibodies in various districts of Tanzania. Vet Res Commun. 33(8):927-36.

27. Faris, D., Yilkal, A., Berhe, G. and Kelay, B. (2012) Seroprevalence and sero-conversion after vaccination against Peste des Petits Ruminants in sheep and goats from Awash Fentale District, Afar, Ethiopia. Prev Vet Med., 103(23):157-62.

28. Rajak, K. K., Sreenivasa, B. P., Hosamani, M., Singh, R. P. Singh, S. K., Singh, R. K. And Bandyopadhyay, S. K. (2005) Experimental studies on immunosuppressive effects of peste des petits ruminants (PPR) virus in goats. Comp. Immunol. Microbiol. Infect. Dis., 28(4):287-296.

29. Kerdiles, Y. M., Cherif, B., Marie, J. C., Tremilon, N., Blanquier, B., Libeau, G., Diallo, A., Wild, T. F., Villiers, M. B. and Horvat, B. (2006) Immunomodulatory properties of morbillivirus nucleoprotein. Viral Immunol., 19(2):324-334.

30. Khan, H. A., Siddique, M., Sajjad-ur-Rahman, Abubakar M. and Ashraf, M. (2008) The detection of antibody against peste des petits ruminants virus in sheep, goats, cattle and buffaloes. Trop Anim Hlth Prod., 40(7):521-7.

31. Raghavendra, A. G., Gajendragad, M. R., Sengupta, P. P., Patil, S. S., Tiwari, C. B., Balumahendiran, M., Sankri, V. and Prabhudas, K. (2008) Seroepidemiology of peste des petits ruminants in sheep and goats of southern peninsular India. RevSciTech., 27(3):861-7.

32. Sande, R., Ayebazibwe, C., Waiswa, F., Ejobi, F. N., Mwiine, W. and Olaho-Mukani, (2011) Evidence of peste des petits ruminants virus antibodies in small ruminants in Amuru and Gulu districts, Uganda. Pak Vet J., 31(4): 363-365.

33. Reoder, P. L., Abrahim, G., Kenfe G. and Barrett, T. (1994) Peste des petits ruminants in Ethiopian goats. Trop. Anim. Health Prod., 26:69-73.

34. El-Yuguda, A. D., Abubakar, M. B., Nabi, A. B., Andrew, A. and Baba, S. S. (2009) Outbreak of PPR in an unvaccinated Sahel goat farm in Maiduguri, Nigeria. J. Biomed. Res., 12: $83-87$.

35. Luther, N. J., Umoh, J. U., Majiyagbe, K. A., Shamaki, D., Nwosuh, C. I. and Dogo, G. (2006) Studies on the prevalence of antibodies to peste des petits ruminants virus (PPRV) among goats in Bauchi state. Nig. Vet. J., (1):17-22.

36. El-Yuguda, A. D., Nabi, A. B., Abubakar, M. B., and Baba, S. S. (2008) Prevalence of PPR cases among Sahel goats presented at the Borno state Veterinary clinic Maiduguri Nigeria from 1996-2005. Nig. Vet. J., 29(1):25-29.

37. Taylor, W. P., Ausaidy, S., and Barrett, T. (1990) The epidemiology of peste des petits ruminants in sultanate of Oman. Vet. Microbial., 22:341-352.

38. Abraham, G., Sintayehu, A., Libeau, G., Albina, E., Roger, F., Laekemariam, Y., Abayneh, D. and Awoke, K. M. (2005) Antibody seroprevalences against peste des petits ruminants (PPR) virus in camels, cattle, goats and sheep in Ethiopia. Prev. Vet. Med., 70:51-7. 